\title{
ANALISIS DESAIN MANAGEMEN SCIENTIFIC LEARNING PROGRAMS DI SEKOLAH DASAR
}

\author{
Rossi Iskandar ${ }^{* 1}$, Arita Marini ${ }^{2}$, Mohamad Syarif Sumantri ${ }^{3}$ \\ ${ }^{1}$ Universitas Trilogi, Jakarta, Indonesian \\ ${ }^{2,3}$ Universitas Negeri Jakarta, Indonesia \\ 1'rossiiskandar@trilogi.ac.id
}

\begin{abstract}
Effective school management is able to optimize the performance of school organization and learning process that is active, collaborative, creative and skilled. The purpose of this research is to explore the application of school-based management through the management of scientific learning programs. Qualitative methods are used to analyze library research data with research objects excavated through a variety of literature information (encyclopedia books, scientific journals, newspapers, magazines, and documents). The results show that the implementation of school-based management will be effective and provide an advantage to school achievement if implemented by all elements involved. In addition, the successful implementation of school-based management requires the socialization, openness, motivation, and unification of the vision of all elements ranging from principals, parents, communities, infrastructure facilities.
\end{abstract}

Keywords: scientific learning programs management design; school-based management

\begin{abstract}
Abstrak
Manajemen sekolah yang efektif adalah mampu mengoptimalkan kinerja organisasi sekolah dan proses pembelajaran yang aktif, kolaboratif, kreatif serta terampil. Tujuan penelitian ini untuk mengeksplorasi penerapan manajemen berbasis sekolah melalui manajemen scientific learning programs. Metode kualitatif digunakan untuk menalisis data kepustakaan (library research) dengan obyek penelitiannya digali melalui beragam informasi kepustakaan (buku ensiklopedi, jurnal ilmiah, koran, majalah, dan dokumen). Hasil menunjukan penerapan manajemen berbasis sekolah akan efektif dan memberikan keunggulan terhadap prestasi sekolah jika dilaksanakan oleh semua unsur yang terlibat. Selain itu keberhasilan implementasi manajemen berbasis sekolah memerlukan adanya sosialisasi, keterbukaan, motivasi, dan penyatuan visi dari semua unsur mulai dari kepala sekolah, orang tua, masyarakat, sarana prasarana.
\end{abstract}

Kata kunci: desain managemen scientific learning programs; manajemen berbasis sekolah

\begin{tabular}{llll}
\hline Received & $: 2021-04-16$ & Approved & $: 2021-06-15$ \\
Reviesed & $: 2021-06-15$ & Published & $: 2021-07-31$
\end{tabular}

(c) (7) (2) Jurnal Cakrawala Pendas is licensed under a Creative Commons Attribution-

SY SA ShareAlike 4.0 International License.

\section{Pendahuluan}

Permasalahan pendidikan di Indonesia sangatlah kompleks. Hal ini mempunyai dampak yang sangat besar bagi majunya kehidupan masyarakat dalam segala aspek bidang kehidupan (Ismail, 2018; Yahya, 2018). Untuk menciptakan masyarakat yang maju, maka yang perlu diperhatikan terlebih dahulu adalah bagaimana mewujudkan pendidikan yang bermutu yang pada akhirnya mencapai tujuan terwujudnya sistem pendidikan yang kuat dan berwibawa untuk memberdayakan semua warga negara Indonesia berkembang menjadi manusia yang berkualitas (Nata, 2017; Oey-gardiner, 2018; Reflianto \& Syamsuar, 2018). Otonomi dalam pendidikan 
perlulah dilaksanakan dalam menjawab tuntutan persaingan global dan dalam menyesuaikan sistem pendidikan dengan perkembangan jaman serta kebijakan yang dibuat oleh pemerintah daerah (Fatmawati, 2018; Mukhsin, 2019). Otonomi daerah ini merupakan implementasi dari azas desentralisasi yang telah diterapkan. Dengan ditetapkannya kebijakan otonomi daerah ini maka mulai dari wilayah provinsi hingga kota/kabupaten akan mengurusi sendiri urusan daerahnya (Kuswandi, 2011). Setiap daerah tersebut akan memiliki wewenang, hak, dan tanggung jawab sendiri untuk mengurus rumah tangganya sesuai dengan batasan dan kewenangan yang diberikan oleh pemerintah pusat.

Seiring dengan kemajuan teknologi dan informasi masih banyak guru yang kurang profesional dibidangnya, seperti adanya guru yang terlambat masuk mengajar, tidak mempunyai perangkat pembelajaran yang lengkap, kurangnya koordinasi antar kepala sekolah dan guru, tidak adanya inovasi untuk meningkatkan kualitas pembelajaran. Maka perlu adanya inovasi dan pengelolaan yang baik yaitu dengan manajemen berbasis sekolah (MBS). MBS merupakan pemikiran ke arah pengelolaan pendidikan yang memberi keleluasaan kepada sekolah untuk mengatur dan melaksanakan berbagai kebijakan secara luas (Hamid, 2018; Pratiwi, 2016).

Peneltian terdahulu mengenai manajemen berbasis sekolah telah banyak dilakukan dengan ragam metode yang dilakukan diantaranya (Damanik, 2019; Hasiba, 2018; Nuzula, 2019; Saberan \& Susilawati, 2019; Suprihatin, 2017) hasil menunjukan penerapan manajemen berbasis sekolah yang baik mampu meningkatkan kualitas mutu pendidikan serta mampu mencapai keunggulan masyarakat bangsa dalam penguasaan ilmu dan teknologi. MBS menuntut terjadinya perubahan dalam manajemen sekolah. Pada prinsipnya, MBS bertujuan untuk memberdayakan sekolah dalam menetapkan berbagai kebijakan internal sekolah yang mengarah pada peningkatan mutu dan kinerja sekolah secara keseluruhan (Asfar \& Asfar, 2019; Pratiwi, 2016; Z. Yusuf \& Mardiana, 2020). Manajemen Berbasis Sekolah yang ditandai dengan otonomi sekolah dan pelibatan masyarakat merupakan respon pemerintah terhadap gejala-gejala yang muncul di masyarakat, bertujuan untuk meningkatkan efisiensi, mutu, dan pemerataan pendidikan. Peningkatan efisiensi antara lain diperoleh melalui keleluasaan mengelola sumber daya partisipasi masyarakat dan penyederhanaan birokrasi. Peningkatan mutu antara lain diperoleh melalui partisipasi orang tua terhadap sekolah, fleksibilitas pengelolaan sekolah dan kelas, peningkatan profesionalisme guru dan kepala sekolah (Sumarsono et al., 2017). Sementara peningkatan pemerataan antara lain diperoleh melalui peningkatan partisipasi masyarakat yang memungkinkan pemerintah lebih berkonsentrasi pada kelompok tertentu.

Berdasar penelitian terdahulu, penerapan MBS diharapkan dapat membuat sekolah lebih mandiri, dengan memberdayakan potensi sekolah melalui pemberian wewenang yang lebih besar kepada sekolah dan mendorong sekolah untuk mengambil keputusan yang partisipatif yang melibatkan semua warga sekolah dan pihak masyarakat. Dengan pengambilan keputusan partisipatif maka rasa memiliki warga sekolah dapat meningkat. Meningkatnya rasa memiliki akan meningkatkan rasa tanggung jawab yang selanjutnya meningkatkan dedikasi warga sekolah terhadap sekolahnya. Peningkatan otonomi sekolah dan pengambilan keputusan partisipatif ditujukan untuk meningkatkan kualitas sekolah. Sebagai salah satu konsep dan paradigma baru pendidikan di era otonomi, MBS berupaya mewujudkan sistem pendidikan yang memberdayakan, demokratisasi yang berorientasi pada kemandirian, kebebasan dan tanggung jawab sekolah (Kurniawati et al., 2020; Triyarsih, 2019). Dari sinilah tujuan utama MBS diperoleh yaitu untuk membuat sekolah lebih independen dan terus menerus meningkatkan kinerja sekolah terutama peningkatan output pendidikan melalui proses belajar mengajar yang bermutu.

Karakteristik MBS yang mesti dipahami oleh penyelenggara pendidikan pada era desentralisasi adalah mengetahui bagaimana sekolah dapat mengoptimalkan kinerja organisasi sekolah, proses belajar mengajar, pengelolaan sumber daya dan administrasi dengan baik seperti menghasilkan output, yaitu prestasi pendidikan serta manajemen sekolah yang efektif dan efisien, kepala sekolah berperan penting dalam menggerakkan, mengkoordinasikan dan menyelaraskan seluruh sumber daya pendidikan yang tersedia, lingkungan belajar yang nyaman, tertib dan aman sehingga manajemen sekolah lebih efektif, melakukan analisa kebutuhan sumber daya mulai dari perencanaan, pelaksanaan, pengembangan hingga evaluasi kerja serta mengatur imbalan jasa 
agar tenaga kependidikan dan pendidik mampu menjalankan tugasnya dengan baik, keterbukaan pihak sekolah kepada publik dalam menunjukkan hasil dari program kerja yang telah dilaksanakan dan pengelolaan anggaran secara terbuka dan administratif sesuai dengan kebutuhan riil sekolah dalam rangka meningkatkan kualitas penyelenggaraan pendidikan (Dkk, 2020; Ibrohim, 2018; Nurokhim, 2017).

Dengan demikian, mahasiswa calon guru Sekolah Dasar semestinya dapat memahami penerapan MBS sebagai bekal ketika berada di sekolah nantinya (Pratiwi, 2016). Otonomi daerah ini diharapkan dapat mengefisienkan pelayanan publik di masyarakat sehingga dalam penerapannya masyarakat menjadi lebih dekat dengan pemerintah. Salah satu bidang yang didesentralisasikan adalah bidang pendidikan, dimana dalam penerapan di sekolah disebut Manajemen Berbasis Sekolah (MBS). Manajemen Berbasis Sekolah ini merupakan kebijakan dalam sistem penyelenggaraan dan pengelolaan sekolah yang dilakukan secara mandiri (Hamid, 2018; Hasiba, 2018; Saberan \& Susilawati, 2019). Sistem ini memberikan peluang bagi sekolah untuk mengatur pengelolaan sekolahnya secara demokratis, professional, dan dinamis. Hal ini dimaksudkan untuk meningkatkan pemerataan pendidikan, mutu sekolah dan peningkatan efisiensi masyarakat. Sehingga pertanyaan dalam penelitian ini adalah bagaimana menyusun desain program pembelajaran ilmiah berbasis manajemen kelas?

\section{Metode Penelitian}

Metode yang digunakan adalah kualitatif dengan jenis penelitan kepustakaan (library research) dengan obyek penelitiannya digali melalui beragam informasi kepustakaan (buku ensiklopedi, jurnal ilmiah, koran, majalah, dan dokumen). Data yang digunakan dalam penelitian ini adalah data sekunder. Teknik analisis data yang digunakan adalah analisis data interaktif dengan menggunakan model Milles dan Huberman, melalui model analisis data tiga langkah yaitu mereduksi data dimana peneliti menelaah, menulis dan merangkum ulang data yang telah didapatkan melalui kegiatan observasi, wawancara dan dokumentasi. Reduksi data ini, dilakukan selama penelitian hingga penulisan laporan selesai yang bertujuan untuk menentukam tema serta data yang dibutuhkan oleh peneliti. Selanjutnya penyajian data yang di peroleh dalam penelitian yang disajikan dalam bentuk uraian singkat yang bersifat naratif teks. Dengan melakukan penyajian data yang sudah didapatkan, peneliti akan lebih mudah untuk memahami apa yang harus di dalami dan dianalis, memutuskan dan merencanakan langkah selanjutnya. Di dalamnya termasuk tahapan perancangan desain, yang bertujuan merancang dan mengaktualisasikan tahapan sebelumnya dalam wujud desain pengembangan, sehingga lebih bisa dipahami. Kemudian menarikan Kesimpulan berdasar data yang telah didapat melalui observasi, diskusi terfokus dan dokumentasi. Berupaya menggambarkan data objek yang belum jelas, menjadi lebih jelas.

\section{Hasil dan Pembahasan}

Penerapan manajemen berbasis sekolah secara efektif dan efisien harus melibatkan semua unsur yang ada mulai dari kepala sekolah, orang tua, masyarakat, sarana prasarana serta unsur terkait lainnya (Hasiba, 2018; Nuzula, 2019; Saberan \& Susilawati, 2019). Melalui era otonomi pendidikan, keluarga dan masyarakat bukan lagi pihak yang pasif hanya penerima keputusankeputusan dalam penyelenggaraan pendidikan. Tetapi mereka harus aktif menentukan dan membuat program bersama sekolah dan pemerintah. Keterlibatan masyarakat dalam programprogram sekolah, dapat dilakukan dengan cara berkomunikasi. Karena pada hakikatnya komunikasi adalah satu bentuk keterlibatan, dan keterlibatan berarti partisipasi aktif masyarakat di dalam program dan kegiatan sekolah. Dalam pelaksanaanya semua komponen sekolah harus meningkatkan kinerja dan profesionalisme kerja dalam upaya peningkatan mutu pendidikan di sekolah (Aisyah, 2021; Indraningrum, 2018). 
Hal ini sangat diperlukan karena untuk mencapai tujuan pendidikan, output yang diperoleh dari proses pendidikan harus memiliki kompetensi sesuai dengan tuntutan dan kebutuhan masyarakat (Budiatman \& Patriasurya, 2019; Retnasari et al., 2020). Dan itu tidak terlepas dari peranan sekolah, seperti kepala sekolah, komite sekolah dan orang tua. Implementasi MBS akan berhasil melalui strategi-strategi sebagai berikut (Nurkolis et al., 2020; Sugianto et al., 2020). Pertama, sekolah harus memiliki otonomi terhadap empat hal, yaitu dimilikinya otonomi dalam kekuasaan dan kewenangan, pengembangan pengetahuan dan keterampilan secara kesinambungan, akses informasi ke segala bagian dan pemberian penghargaan kepada setiap pihak yang berhasil . Kedua, adanya peran serta masyarakat secara aktif dalam hal pembiayaan, proses pengambilan keputusan. Ketiga, adanya kepemimpinan sekolah yang kuat sehingga mampu menggerakkan dan mendayagunakan sumber daya sekolah secara efektif. Keempat, adanya proses pengambilan keputusan yang demokratis dalam dewan sekolah yang aktif. Kelima, semua pihak harus memahami peran dan tanggungjawabnya secara sungguh-sungguh. Keenam, adanya guidelines dari Departemen Pendidikan terkait sehingga mampu mendorong proses pendidikan di sekolah secara efektif dan efisien. Ketujuh, sekolah harus memiliki transparansi akan akuntabilitas yang minimalnya diwujudkan dalam laporan pertanggungjawaban setiap tahunnya. Akuntabilitas sebagai bentuk pertanggungjawaban sekolah terhadap semua stakeholder. Kedelapan, penerapan MBS harus diarahkan untuk pencapaian kinerja sekolah dan lebih khusus lagi adalah meningkatkan pencapaian belajar siswa. Kesembilan, implementasi diawali dengan sosialisasi konsep MBS, identifikasi peran masingmasing.

Dalam mendesain suatu Manajemen berbasis sekolah, misalnya dalam aspek program sekolah, seyogyanya kepala sekolah beserta dengan warga sekolah dan melibatkan unsur masyarakat (komite sekolah) mengetahui beberapa prinsip dan analisis dalam rangka merencanakan program sekolah berbasis MBS, khususnya di sekolah Dasar (Iskak, 2018; Ramdan et al., 2019) yaitu, (1) desain dan aplikasi perumusan program kelembagaan institusi sekolah dasar, dalam menyusun program sekolah atau kelembagaan seyogyanya, warga sekolah meliputi Pendidik dan Tenaga Kependidikan harus mempertimbangkan dan menyelaraskan dengan standar nasional pendidikan, kurikulum, tujuan dan evaluasi pembelajaran, guna menjadikan program yang disusun menjadi relevan dan dapat diterapkan dan dirasakan langsung manfaatnya. (2) Mekanisme penyusunan program kelembagaan pada jenjang Sekolah Dasar, dalam menyusun program kelembagaan sekolah, seyogyanya harus memahami dam mempertimbangkan beberapa hal yang ikut menentukan keberhasilan suatu program yang akan dilaksanakan, yakni tujuan nasional, standar nasional pendidikan, faktor pendidik, tenaga kependidikan, kurikulum, dan kebijakan sekolah. (3) Evaluasi program kelembagaan, dalam

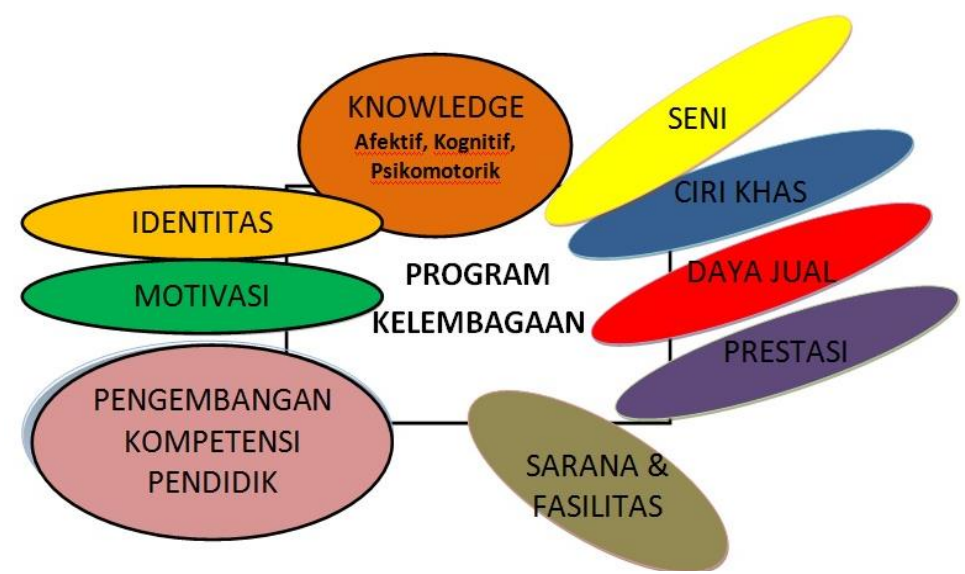

Gambar. 1. Konstelasi Urgensi Dalam Fasilitasi Program Kelembagaan Dan Pembelajaran Jenjang Sekolah Dasar 
menyusun evaluasi perlu dilakukan pengukuran dan penilaian yang digunakan untuk menentukan keberhasilan aktivitas pendidikan dalam hal ini merupakan program perbaikan.

Selanjutnya, Desain Managemen Scientific Learning Programs merupakan suatu program pembelajaran ilmiah yang disusun dan dirancang dengan terarah, dengan tujuan memberikan aktivitas pembelajaran yang aktif, kolaboratif, kreatif dan keterampilan sosial (Rahmat, 2019). Desain Managemen Scientific Learning Programs dirancang dalam bentuk program sekolah atau bisa juga kearah khusus yakni program pembelajaran kelas. Desain Managemen Scientific Learning Programs dijadikan sebagai salah satu solusi untuk memberikan optimasisasi dan penguatan keterampilan kolaboratif pada diri siswa. Desain Managemen Scientific Learning Programs disusun berdasarkan atas beberapa analisis utama sebagai mana dinyatakan dalam gambar berikut.

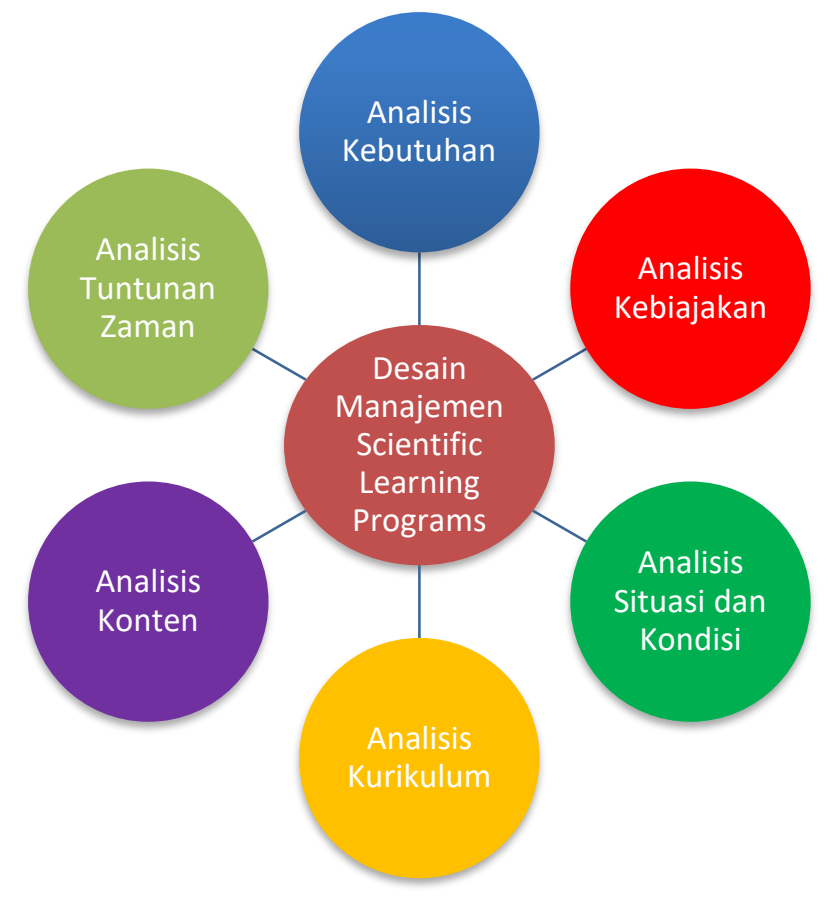

Gambar 2. Analisis Perencanaan Desain Managemen Scientific Learning Programs

Desain Managemen Scientific Learning Programs berdaskan analisis yang matang yang yakni analisis kebutuhan meliputi tuntutan kurikulum, tuntutan institusi, tuntutan kebutuhan siswa dan pemecahan problematika lapangan. Karakteristik program harus dibuat berdasarkan pertimbangan yang mendasar, yakni berdasarkan atas aturan dan dasar-dasar tujuan pendidikan nasional, standar nasional pendidikan, visi misi sekolah, tuntutan zaman dan sesuai dengan tuntutan kurikulum. Penyusunan Desain Managemen Scientific Learning Programs berdasarkan situasi dan kondisi didasarkan atas kondisi keadaan dan ketersediaan sarana dan prasarana yang mendukung keterlaksanaan program yang dibuat. Program yang dibuat disusun dan dirancang selaras dengan kondisi dan kesiapan intansi untuk menjalankan program. Desain Managemen Scientific Learning Programs disusun berdasarkan konten, didasarkan atas konten dan muatan pembelajaran yang bermuatan kinerja ilmiah dan pemecahan masalah. Hal ini dimaksudkan guna untuk memberikan ruang dan aktivitas pembelajaran yang berorientasi terhadap siswa. Konten yang dimamsud meliputi konten materi, konten isi dan substansi tujuan pembelajaran.

Desain Managemen Scientific Learning Programs disusun berdasarkan tuntutan zaman mengindikasikan program yang dibuat memberikan pengalaman dan pembelajaran yang terbarukan kepada siswa, serta dapat memberikan berbagai kemudahan dalam proses pembelajaran di sekolah. Desain Managemen Scientific Learning Programs disusun berdasarkan tuntutan kurikulum akan memudahkan terlaksananya program yang dibuat serta relevan dengan materi pembelajaran. Dalam hal ini program yang dibuat dan disusun memberikan fasilitas dan 
wadah untuk siswa dalam rangka mengembangkan bakatnya sesuai kompetensi dasar serta sesuai dengan bidang yang diminatinya.

Desain Managemen Scientific Learning Programs disusun berdasarkan atas kesesuaikan dan dipertimbangkan dengan sarana dan prasarana yang tersedia dan mendukung pada kelembagaan. Dengan hal demikian akan memberikan kemudahan dan analisis mengenai program apa saja yang dapat dilaksanakan dalam suatu lembaga, sehingga dimungkinkan pula dapat mengurangi terjadinya permasalahan dalam pelaksanaannya. Desain Managemen Scientific Learning Programs disusun berdasarkan kebijakan merupakan dasar perencanaan program berdasarkan atas kebijakan institusi sekolah atau lembaga untuk memberikan ciri khas/ simbol terhadap sekolah, serta ditetapkan berdasarkan kebijakan warga sekolah dan masyarakat. Program yang dibuat berdasarkan kekhasan dapat memberikan keunikan dan kelebihan tersendiri kepada lembaga , sehingga masyarakat dapat mengetahui kelebihan sekolah dan berbagai program unggulan sekolah. Secara garis besar gambaran dan substansi Desain Managemen Scientific Learning Programs dinayatakan dalam gambar berikut.

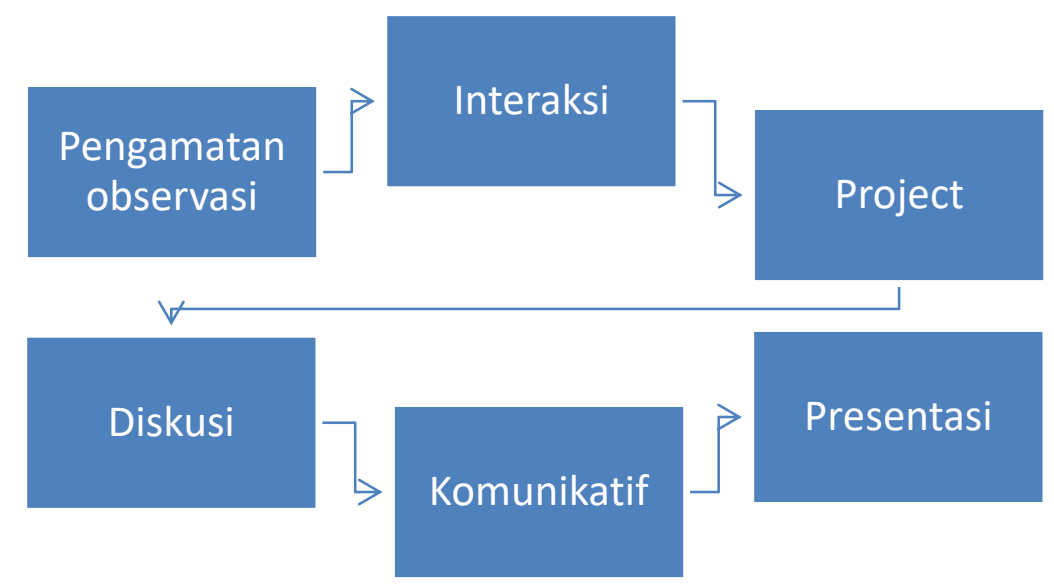

Gambar 3. Konstelasi Desain Managemen Scientific Learning Programs Dalam proses pembelajaran

Berdasarkan gambar 3 di atas, Desain Managemen Scientific Learning Programs disusun dengan memuat substansi Pengamatan / Observasi, Komunikatif, Presentasi, Interaksi dan Project / unjuk kerja. Dalam menyusun program pembelajaran berbasis ilmiah seyogyanya, guru harus mempertimbangkan dan menyelaraskan dengan standar nasional pendidikan, kurikulum, tujuan dan evaluasi pembelajaran, guna menjadikan program yang disusun menjadi relevan dan dapat diterapkan dan dirasakan langsung manfaatnya. Desain Managemen Scientific Learning Programs adalah salah satu sampel ide gagasan dari orientasi baru dalam pendidikan berupan penerapan berbagai metode, media, konsep dan aktivitas belajar siswa secara terprogram. Pada hakikatnya Desain Managemen Scientific Learning Programs ini adalah suatu design managemen sekolah dan kelas yang bertujuan untuk meningkatkan proses pembelajaran yang aktif, kreatif dan menyenangkan. Suatu program tidak akan berjalan tanpa adanya rancangan yang kuat akan indikator capaian program yang ditentukan.

Mencermati temuan penelitian di atas maka penerapan manajemen berbasis sekolah akan efektif dan memberikan keunggulan terhadap prestasi sekolah jika dilaksanakan oleh semua unsur yang terlibat baik kepala sekolah, komite sekolah dan lainya. Hal itu sesuai denga apa yang di sampaikan (Bafadal et al., 2019; Yulianti, 2020; H. A. Yusuf et al., 2019) bahwa manajemen berbasis sekolah, kepemimpinan berbasis sekolah, serta manajemen dan kepemimpinan memiliki efek positif pada prestasi sekolah. Keterbatasan penelitian hanya mengkaji dan menganalisis secara literature dengan berbagai penelitian terdahulu, maka penelitian selanjutnya perlu dikembangkan Desain Managemen Scientific Learning Programs sesuai kebutuhan sekolah dan peserta didik. 


\section{Kesimpulan}

Manajemen Berbasis Sekolah (MBS) yaitu model pengelolaan yang memberikan otonomi atau kemandirian kepada sekolah dan mendorong pengambilan keputusan partisipatif yang melibatkan secara langsung semua warga sekolah sesuai dengan standar pelayanan mutu yang ditetapkan oleh pemerintah pusat, provinsi, kabupaten dan kota. Keberhasilan penerapan manajemen pendidikan berbasis sekolah sangat ditentukan oleh political will pemerintah dan kepemimpinan di persekolahan. Penerapan MBS yang efektif seyogianya dapat mendorong kinerja kepala sekolah dan guru yang pada gilirannya akan meningkatkan prestasi murid. Sehingga dengan Desain Managemen Scientific Learning Programs mampu menyususn pembelajaran sesuai tuntutan zaman serta mengindikasikan program yang dibuat memberikan pengalaman dan pembelajaran yang terbarukan kepada siswa, sehingga dapat memberikan berbagai kemudahan dalam proses pembelajaran di sekolah.

\section{Daftar Pustaka}

Aisyah, S. (2021). Peran Manajemen Berbasis Sekolah Dalam Meningkatkan Partisipasi Masyarakat di MTS AL-Faaizun Watang Palakka. Equilibrium: Jurnal Pendidikan, 9(1). https://doi.org/10.26618/equilibrium.v9i1.3805

Asfar, A., \& Asfar, A. M. I. A. (2019). Integrasi Manajemen Berbasis Sekolah (MBS): Kepemimpinan Kepala Sekolah. Universitas Negeri Ma Assar. Hal.

Bafadal, I., Wiyono, B. B., \& Sobri, A. Y. (2019). The implementation of school based management, and its effect on the teachers' work motivation and the school quality. Universal Journal of Educational Research, 7(9). https://doi.org/10.13189/ujer.2019.070925

Budiatman, I., \& Patriasurya, A. (2019). Teknik Pembelajaran Yang Efektif Dalam Disain Pembelajaran Kooperatif Untuk Mata Pelajaran Ips. Jurnal Cakrawala Pendas, 5(2). https://doi.org/10.31949/jcp.v5i2.1318

Damanik, R. (2019). Pengaruh Manajemen Berbasis Sekolah Dan Komite Sekolah Terhadap Mutu Sekolah. Serunai: Jurnal Ilmiah Ilmu Pendidikan, 5(1). https://doi.org/10.37755/sjip.v5i1.153

Dkk, A. W. (2020). Manajemen berbasis sekolah :Konsep, strategi dan perencanaan. In Solo : Yayasan Kita.

Fatmawati, F. (2018). Etika Otonomi Daerah dalam Perspektif Filsafat Pendidikan. Jurnal Agregasi: Aksi Reformasi Government Dalam Demokrasi, 6(1). https://doi.org/10.34010/agregasi.v6i1.848

Hamid, H. (2018). Manajemen Berbasis Sekolah. Al-Khwarizmi: Jurnal Pendidikan Matematika Dan Ilmu Pengetahuan Alam, 1(1). https://doi.org/10.24256/jpmipa.v1i1.86

Hasiba, C. (2018). Penarapan Manajemen Berbasis Sekolah (MBS) Dalam Organisasi dan Administrasi Pendidikan Sebagai Inovasi Pembelajaran. World Development, 1(1).

Ibrohim, B. (2018). Manajemen Berbasis Sekolah: Strategi Alternatif Dalam Persaingan Mutu. Tarbawi: Jurnal Keilmuan Manajemen Pendidikan, 4(01). https://doi.org/10.32678/tarbawi.v4i01.836

Indraningrum, E. (2018). Peran Kepala Sekolah dan Partisipasi dari Masyarakat dalam Implementasi Manajemen Berbasis Sekolah unruk Mewujudkan Kualitas Pendidikan Madrasah Tsanawiyah Negeri Kota Madiun. Gulawentah:Jurnal Studi Sosial, 3(1). https://doi.org/10.25273/gulawentah.v3i1.2826

Iskak, W. (2018). Grand Desain Sms Dalam MBS Untuk Mewujudkan Sekolah Yang Efektif Dan Unggul. CENDEKIA: Jurnal Studi Keislaman, 2(1). https://doi.org/10.37348/cendekia.v2i1.19

Ismail, F. (2018). Mengurai Problematika Pendidikan Indonesia (Upaya Menjawab Tantangan Zaman). Jurnal Ilmiah Iqra', 3(2). https://doi.org/10.30984/jii.v3i2.558

Kurniawati, E., Arafat, Y., \& Puspita, Y. (2020). Peran Kepemimpinan Kepala Sekolah dalam Meningkatkan Mutu Pendidikan melalui Manajemen Berbasis Sekolah. Journal of Education Research, 1(2). https://doi.org/10.37985/joe.v1i2.12

Kuswandi, A. (2011). Desentralisasi Pendidikan Dalam Penyelenggaraan Otonomi Daerah Di 
Indonesia. Governance (Jurnal Ilmu Pemerintahan), 2(1).

Mukhsin, M. (2019). Strategi Peningkatan Mutu Di Era Otonomi Pendidikan. JUPE : Jurnal Pendidikan Mandala, 4(5). https://doi.org/10.36312/jupe.v4i5.845

Nata, A. (2017). Pendidikan Islam di Indonesia: Tantangan dan Peluang. EDUKASI: Jurnal Penelitian Pendidikan Agama Dan Keagamaan, 2(1). https://doi.org/10.32729/edukasi.v2i1.352

Nurkolis, N., Setyaningsih, R., \& Roshayanti, F. (2020). Manajemen sekolah berbasis literasi lingkungan untuk meningkatkan kesadaran siswa terhadap lingkungan sekolah. Jurnal Administrasi Pendidikan, 27(1). https://doi.org/10.17509/jap.v27i1.24393

Nurokhim, N. (2017). Manajemen Berbasis Sekolah: Solusi Peningkatan Mutu Pendidikan Madrasah. Jurnal Kependidikan, 5(2). https://doi.org/10.24090/jk.v5i2.1925

Nuzula, W. F. (2019). Peran Kepala Sekolah Dalam Implementasi Manajemen Berbasis Sekolah. Pena Islam, Jurnal Pendidikan Agama Islam, 3(1).

Oey-gardiner, M. (2018). Tantangan Pendidikan Tinggi Indonesia di Era Disrupsi dan Globalisasi. Sdg Center Unpad.

Pratiwi, S. N. (2016). Manajemen Berbasis Sekolah Dalam Meningkatkan Kualiats Sekolah. Jurnal EduTech, 2(1).

Rahmat, A. S. (2019). Design Managemen Scientifict Learning Programs Sebagai Penguatan Aktivitas Belajar Kolaboratif Siswa Abad 21. Jurnal Penelitian Kebijakan Pendidikan, 10(3). https://doi.org/10.24832/jpkp.v10i3.239

Ramdan, M., Hikmah, A. B., \& Apriyani, Y. (2019). Sistem Informasi Manajemen Laboratorium Sekolah Berbasis Web Pada SMK Muhammadiyah Kawali. Indonesian Journal on Software Engineering (IJSE), 5(2). https://doi.org/10.31294/ijse.v5i2.6961

Reflianto, \& Syamsuar. (2018). Pendidikan dan Tantangan Pembelajaran Berbasis Teknologi Informasi di Era Revolusi Industri 4.0. Jurnal Ilmiah Teknologi Pendidikan, 6(2).

Retnasari, L., Hidayah, Y., \& Dianasari, . (2020). Urgensi Bahan Ajar Materi Pembelajaran Ppkn Sd Untuk Membangun Kompetensi Pedagogik Calon Guru Sekolah Dasar. Jurnal Cakrawala Pendas, 6(2). https://doi.org/10.31949/jcp.v6i2.2186

Saberan, R., \& Susilawati, E. (2019). Penerapan Manajemen Berbasis Sekolah. Lentera: Jurnal Pendidikan, 14(2). https://doi.org/10.33654/jpl.v14i2.849

Sugianto, S., Nurkolis, N., \& Egar, N. (2020). Manajemen Sekolah Adiwiyata Di SMK Negeri 1 Adiwerna Kabupaten Tegal. Jurnal Manajemen Pendidikan (JMP), 8(1). https://doi.org/10.26877/jmp.v8i1.5370

Sumarsono, R. B., Benty, D. D. N., Wiyono, B. B., Maisyaroh, \& Supriyanto, A. (2017). Implementasi Manajemen Berbasis Sekolah Sebagai Upaya Peningkatan Mutu Pendidikan Sekolah. Abdimas Pedagogi, 1(1).

Suprihatin, B. (2017). Meningkatkan Profesionalisme Guru Melalui Implementasi Manajemen Berbasis Sekolah ( MBS ) di SD Sahara Kabupaten Bandung. Jurnal Ekonomi, Bisnis \& Entrepreneurship, 11(2).

Triyarsih, M. G. (2019). Implementasi Manajemen Berbasis Sekolah Dalam Pembentukan Karakter Siswa Sekolah Dasar. Media Manajemen Pendidikan, 2(1). https://doi.org/10.30738/mmp.v2i1.4028

Yahya, M. (2018). Era Industri 4.0: Tantangan dan Peluang Perkembangan Pendidikan Kejuruan Indonesia. Orasi Ilmiah Professor Bidang Ilmu Pendidikan Kejuruan Universitas Neegeri Makassar.

Yulianti. (2020). The effect of school-based management on school achievements in elementary schools. International Journal of Innovation, Creativity and Change, 13(2).

Yusuf, H. A., Amzat, I. H., \& Saidin, K. B. (2019). The mediating effect of school-based management on school climate, bureaucracy and effectiveness in secondary schools. Malaysian Online Journal of Educational Management, $7(3)$. https://doi.org/10.22452/mojem.vol7no3.2

Yusuf, Z., \& Mardiana, D. (2020). Manajemen Berbasis Sekolah sebagai Landasan Kepala Sekolah dalam Peningkatan Mutu Pendidikan Agama Islam. QALAMUNA: Jurnal Pendidikan, Sosial, Dan Agama, 12(01). https://doi.org/10.37680/qalamuna.v12i01.152 